\title{
A STRATEGY FOR MARKETING CULTURAL HERITAGE AS AN ENTRY POINT TO ACHIEVE SUSTAINABLE HUMAN DEVELOPMENT FOR THE ADVANCEMENT OF THE EGYPTIAN ECONOMY
}

\author{
Ansar Muhammad Awad Allah RIFAI*
}

Fundamentals of Art Education, Faculty of Art Education, Helwan University, Egypt.

\begin{abstract}
Our nation possesses a cultural heritage spanning thousands of years, representing an intertwining and interwoven mixture of thought, culture and creativity that reflects the collective unconscious of the nation characterized by diversity and richness within the framework of the organic unity of society that gives it its distinct privacy and cultural uniqueness. Its vitality and presentation, in the past and present, and the cultural heritage is linked to the religious, aesthetic, creative, intellectual, philosophical, historical and social context of the nation. After the end of the cultural Cold War and the domination of the unipolar culture, and in light of the challenges of cultural globalization, the nation must free itself from dependency in order to have the freedom to establish its own philosophy stemming from the ground of its cultural specificity, and to create its own vision to achieve its civilizational mission of building the earth according to its global vision and the pillars Its identity, distinct from other nations, which was creatively expressed in the form of its material and intangible cultural heritage, and made cultural heritage a starting point for contemporary through criticism, analysis, judgment and selection in proportion to it.

Keywords

Strategy, Marketing, Cultural Heritage, Sustainable Development, Egyptian Economy.
\end{abstract}

\section{Introduction}

Our nation possesses a cultural heritage spanning thousands of years, representing an intertwining and interwoven mixture of thought, culture and creativity that reflects the collective unconscious of the nation characterized by diversity and richness within the framework of the organic unity of society that gives it its distinct privacy and cultural uniqueness. Its vitality and presentation, in the past and present, and the cultural heritage is linked to the religious, aesthetic, creative, intellectual, philosophical, historical and social context of the nation. After the end of the cultural Cold War and the domination of the unipolar culture, and in light of the challenges of cultural globalization, the nation must free itself from dependency in order to have the freedom to establish its own philosophy stemming from the ground of its cultural specificity, and to create its own vision to achieve its civilizational mission of building the earth according to its global vision and the pillars Its identity, distinct from other nations, which was creatively expressed in the form of its material and intangible cultural heritage, and made cultural heritage a starting point for contemporary through criticism, analysis, judgment and selection in proportion to it. And the needs of contemporary reality, and this will only be achieved through a renewed vision of the heritage, in which the criterion for renewal becomes that it is able to develop solutions to contemporary economic problems, a renewed vision through which the hopes, dreams and aspirations of the nation are fulfilled at all aesthetic, intellectual, economic and developmental levels, and that is through stimulating values Heritage to turn into activities that contribute to building the renaissance of the nation, qualifying it to embark on sustainable development programs and strategies, which represents a momentum and a source of confidence for future generations, so that they live connected to their culture and heritage and work to activate them in the future, which establishes the values of belonging and rooting of identity.

The aim of the proposed strategy for marketing cultural heritage is to contribute to economic development based on marketing cultural heritage, and to bring about a radical and structural change in economic and social activity to ensure the creation of investment opportunities, and to achieve a continuous increase in national income and the Egyptian economy, in order to achieve sustainable development for future generations through Developing cultural heritage as the most important material resource and marketing it to achieve the maximum possible benefit, especially in light of the global interest in the growth of the creative economy, which has achieved many changes in the nature of creative investments and creativity management in global and contemporary economies.

* Corresponding author: art_education@helwan.com 


\section{Results and Recommendations:}

\section{First: Results:} development.

1- Marketing of Egyptian cultural heritage is an important entry point to achieve sustainable human

2 - Building a strategy for marketing cultural heritage.

3- Achieving human development through cultural heritage.

4- Investing cultural heritage in order to advance the Egyptian economy.

\section{Second: Recommendations:}

1- Enriching the effectiveness of the economic and developmental role to create investment opportunities through building a proposed strategy marketing cultural heritage, traditional arts and crafts.

2- Directing the attention of those in charge of preserving and developing heritage on the importance of marketing heritage creations and activating them creatively in heritage arts and crafts.

3- Opening new horizons in the field of economic assets for art education in finding new approaches to marketing cultural heritage.

\section{References}

1- Amartya Sen (2009): Development as Freedom, World Knowledge Series, Kuwait, Egyptian Council for

Culture and Literature.

2- Hassan Hanafi: The Concerns of Thought and the Homeland, C1, Cairo, The Anglo-Egyptian Library.

3- Rania Hassan Abdo Al-Khawas (2012): An example of a proposed guide based on the link between the strategy of individualizing education and the comprehensive evaluation system, an unpublished $\mathrm{PhD}$ thesis, Faculty of Art Education, Helwan University.

4- Saad Allam Taha (2012): Human Development Economics, Cairo, The Anglo-Egyptian Library.

5- Said Taha Allam, Farid Ahmed Abdel-Al (2012): The Economics of Human Development, Cairo, The Anglo-Egyptian Library.

6- Lawrence E. Harrison, Samuel B. Huntington (2009): Cultures and Values of Progress, translated by Shawqi Jalal, Cairo: The Cultural Center for Translation.

7- ar.unesco.org/node/250717

8- ar.unesco.org/themes/protecting-our-heritage-and fostering creativity

9- http://historicalcities.wordpress.com/

10- Asaad Jawad Kazim (2009): Sustainable human development and inviting economic thought to the breadth of humanity

11- www.unesco.org/

Received: February 25, 2018

Accepted: April 2, 2018 